\title{
Lumen
}

Selected Proceedings from the Canadian Society for Eighteenth-Century Studies

\section{Eric Voegelin's Analysis of the Deformation of Consciousness in Voltaire}

\section{Barry Cooper}

Volume 15, 1996

URI : https://id.erudit.org/iderudit/1012472ar

DOI : https://doi.org/10.7202/1012472ar

Aller au sommaire du numéro

Éditeur(s)

Canadian Society for Eighteenth-Century Studies / Société canadienne d'étude du dix-huitième siècle

ISSN

1209-3696 (imprimé)

1927-8284 (numérique)

Découvrir la revue

Citer cet article

Cooper, B. (1996). Eric Voegelin's Analysis of the Deformation of Consciousness in Voltaire. Lumen, 15, 37-55. https://doi.org/10.7202/1012472ar 


\section{Eric Voegelin's Analysis of the Deformation of Consciousness in Voltaire}

The text I intend to consider has been published as the first chapter of Eric Voegelin's From Enlightenment to Revolution. ${ }^{1}$ This book, edited by John $\mathrm{H}$. Hallowell, is a fragment of a projected multi-volume study of Western political ideas. It was begun during the early 1940 s and was reformulated during the late 1940s and early 1950s as the first three volumes of Order and History. Order and History was itself restructured during the 1960s and 1970s with the publication of Anamnesis in 1966, and of vol. IV, The Ecumenic Age in 1974. ${ }^{2}$ I mention this philological information in order to indicate that Voegelin's analysis of Voltaire was undertaken at a comparatively early stage in the development of his political science or political philosophy. He was, as he said, 'working through the materials' that constituted what was conventionally called the history of western political thought, an academic topic indicated by the now somewhat dated Plato-to-NATO survey courses offered to undergraduates in political science. At approximately the same time he developed the initial formulation of his philosophy of consciousness. The two elements of this intellectual development did not come together into a coherent and explicit whole until much later in Voegelin's life. It would, no doubt, be possible to formulate a coherent account of the somewhat inchoate philosophy of consciousness that Voegelin had developed during the 1940s. The focus here, however, is on Voltaire's 'philosophy of history.' The assumption we make is that the peculiarities of his 'philosophy of history' provide clues to the deformations of consciousness that generated it, that gave it the support it had, and that even today makes Voltaire a writer easily accessible to contemporary audiences.

We may begin by observing that the term 'philosophy of history' was apparently coined by Voltaire. As a rule of thumb in the study of the 'history of ideas' terminological innovations such as 'history of ideas' itself, have usually been introduced in response to historical and experiential novelties. This was true of Voltaire's invention.

During the two or three centuries prior to the publication of Voltaire's Essai sur les moeurs et l'esprit des nations (1756) a complex configuration 
of historical events conspired to create in the minds of those who reflected upon them a sense that an epoch had ended. First of all, the Reformation had fractured the Church in the West as an institutional representation of humanity. Frederick the Great expressed a new political consciousness when, in 1740 he offered Voltaire his views on the significance of the death of Charles VI. 'The Emperor is dead,' wrote Frederick, 'now is the moment for a complete change in the old political system. ${ }^{3}$ His remarks reflected the fact that a plurality of sovereign states in a quasi-constitutional balance with one another existed as ultimate political units with little or no relation to the Empire. The new world had been discovered and was in the process of being settled by Europeans. Reports by French Jesuits had brought the civilization of China within the ken of all educated Europeans and trade with Asia was begun more or less on a basis of equality. More importantly, the immense size and civilizational grandeur of Asiatic societies put the orbis terrarum of classical antiquity in a new perspective. For the first time in modern Europe, there was a widespread awareness that Christian civilization could be measured by standards other than its own. Accordingly, the necessity to elaborate an 'idea of man' that could serve as a basis for understanding law, politics and ethics, but that was not limited by what was seen to be the apparent parochialism of Christianity, was increasingly widely felt.

That something new was in the air, then, was obvious to all who had the leisure to consider the question and not simply to scholars. One such, the Marquise du Châtelet-Lorraine, expressed the new self-understanding in two queries, written in the margin of Bossuet's Discours sur l'Histoire Universelle (1681), which was the last 'theology of history' written along the lines of Augustine's City of God. In the first of her notes, she questioned the significance of the Jews for 'history' and in the second, she wondered about the preeminence of Rome, as compared to the much greater significance that ought be accorded the Russian Empire. The Marquise did not initiate an historiographic revolution so much as by her intelligent naivete indicate that one had already occurred.

According to Bossuet, as to Augustine, history was guided by providence so that humans ought neither unduly to fear terrestrial misery nor unduly to admire terrestrial grandeur. Whatever the fortunes of a Christian people, whether for apparent good or ill, they were in the hands of God. One may say, therefore, that Bossuet's Discours was written on the basis of a Christian anthropology. The Christian account of human being accordingly provided the criteria of relevance for his selection of historical evidence presented in the Discours.

Bossuet's book was divided into three parts. The first began with the creation of the world and surveyed events from Adam to Charlemagne. He made no distinction in Part I between what we might call profane 
and sacred events but rather conflated the two in a complex mixture of ages and epoches. The seventh and last age was initiated with the birth of Christ; the establishment of the Western Christian Empire by Charlemagne and its continuation by the French monarchy made it a edifying manual for the instruction of his royal and noble pupils. The second part corresponded to St. Augustine's sacred history in the strict sense and consisted in a presentation of the unfolding of religious history, especially as concerned the Jews, the appearance of Christ, and the history of the Church. The third part discussed the history of empires, understood as a story of educational tribulation. The chief beneficiaries of imperial history had been the Jews, though Bossuet also saw God's plan at work in the coincidence of the Roman imperial unification of the Mediterranean basin with the evangelical spreading of the Gospel and the establishment of the Church. As late as 1681, then, the Christian 'idea of man' was able to provide criteria for ordering history into a meaningful story.

By questioning the significance of the Jews and of Rome, the Marquise du Châtelet was, in fact, challenging the Christian anthropology that provided the context within which the historical position of the Jews and of Rome were meaningfully situated. For the Marquise, as for her witty correspondent, Voltaire, Christianity was an event 'in' history, which in turn had to be meaningful on the basis of some other and larger contextual 'idea.' Christianity was not, therefore, understood as the spiritual drama of humanity whose successive scenes constituted the pragmata of history. Whereas for Bossuet sacred and profane were intermingled but distinguishable, for the Marquise and for Voltaire the distinction between the two was false. By this account, 'really' there was but a singular secular history, an inner-worldly chain of events, an immanent stream of genesis. Anything else, Voltaire once remarked, was 'a pack of tricks we play on the dead.' In consequence, sheer quantitative greatness became the defining factor of significance. For the Marquise, Rome had no universalist symbolical meaning and so was retired to the status of a limited historical phenomenon.

Voltaire was impressed with the remarks of his quondam hostess and patron and undertook to respond to them in his Essai. His term, 'philosophy of history,' was therefore polemical, developed in direct opposition to Bossuet's 'theology of history.' Voltaire's criticism rested on two points: first, Bossuet's allegedly universal history was in fact not universal at all. He considered only four empires of antiquity, after all, and said nothing of the Russians, as the Marquise had observed. Nor, of course, were the Chinese or Indians included in this putative universe. What was worse, said Voltaire, when Bossuet did consider the empires of antiquity, he made it appear as if they were concerned chiefly to instruct the Jews, which provided Voltaire with the occasion for a joke. ${ }^{5}$ In 
contrast, Voltaire declared he 'would speak of the Jews as of Scythians or Greeks.' Now in point of fact, Bossuet was perfectly well aware that the significance of the Jews lay in the spiritual drama of religious life not in the secular changes of empire. Voltaire was obliged, therefore, to answer the question: if Bossuet's history was in fact parochial, not universal, in what did universal history consist?

Before considering Voltaire's response, we may note his second objection to Bossuet, namely that there was no evidence of providential guidance to the course of history. This apparently fatal objection depended for its force on a coherent analysis of the significance of providence. Unfortunately Voltaire had only the haziest understanding of what Bossuet meant by the term. Very approximately, and in the context of his theology of history, divine providence for Bossuet symbolized the experience of anticipation of the Parousia. Faith and trust in God's ultimate deliverance and final salvation were clearly central elements in the Christian 'idea of man.' Both the Creation of the world by God and its eschatological transfiguration expressed the substance of Christian universality, but neither the Beginning nor the End were historical events, properly speaking. In fact, Bossuet's own account of universal history was cast in an idiom far more doctrinal than this summary suggests. The doctrinal language he used, moreover, was an additional occasion for the display of Voltairean wit, perhaps even a provocation for it.

Voltaire's response to his second criticism of Bossuet, namely that his allegedly universal history had forgotten about the universe and substituted fable, was to claim that his Essai was merely a supplement and correction to Bossuet's Discours. In fact, however, it was an attempt to replace it root and branch. Voltaire allowed as Bossuet had provided a splendid account of antiquity, even though he overemphasized the importance of Israel. His first task, then, was to supply the missing data relative to China, India, Persia and Islam, and to continue Bossuet's European narrative from Charlemagne to Louis XIII.

Voltaire's criticism was not without value. Clearly China and India would have to be related to Western Christian history, but how? We may sharpen the theoretical issue by considering the following: Bossuet's universalism depended on the validity of his account of the Beginning and the End. Those two world-transcendent 'events' were not part of the historical narrative but rather endowed it with its meaningful and providential form. By Bossuet's account, unity of meaning was ensured by the universality of the Christian spiritual drama: as with Augustine, sacred history governed the meaning of profane history. And yet, this spiritual drama, its universalist form notwithstanding, ignored India and China. But then, by what right did it claim to be universal? How 
could the empirical or profane history of non-Christian societies and civilizations be integrated into the putatively universal Christian drama of humanity? That was the real and theoretically interesting question raised by Voltaire.

His response to it was to undertake an up-to-date quasi-encyclopedic survey of historical phenomena. Such an enterprise was questionable for two reasons. First, it would have to be revised as additional knowledge came to light. But second, and more fundamentally, even if Voltaire (or any other historian) was able to provide a complete account of every historical event, the encyclopedic result would not necessarily contain any unity of meaning. Of course, the encyclopedic information contained in handbooks is useful, but criteria of meaning must be established on other grounds. And, in fact, Voltaire did undertake to construct a unity of historical meaning on non- and indeed on anti-Christian grounds.

The purpose of his Essai was not, he said, to recount the detail of facts but to tell l'histoire de l'esprit humain. The plot of this story of the human spirit was clear: it consisted in tracing 'the steps by which we have advanced from the barbarian rusticity of [feudal] times to the politesse of our own. ${ }^{6}$ Voltaire was confident that his Essai would bring these step to light because, as he said with deceptive candor, he had selected the facts with considerable care. Contemplating this array of facts, he believed all reasonable men would conclude that the story was, indeed, of the 'extinction, rebirth and progress of the human spirit."

Voltaire's remark was a transparent petitio principii. The structure of his account, however, copied that of Bossuet. Parallel to the universal Biblical story of the creation and decent of mankind was the aforementioned encyclopedic, textbook completeness; parallel to the presence of the Holy Spirit was the intramundane esprit humain; parallel to the apocalyptic transfiguration of the end of days was the ecumenic spread of politesse; the historical extinction, rebirth and progress of the human spirit was the secular equivalent to the Christian drama of the fall of humanity in the story of Adam, the redemption of humanity in the story of Christ, and the transfiguration of humanity in the evocation of the Last Judgement.

Voltaire had, in short, constructed a complex series of categories that were both analogous to Christianity and derived from it. The purpose of doing so was to formulate a secular equivalent to the interpretative categories of Christian sacred history. In this way, he believed he could create a context within which the expanded array of historical materials that fell under his notice could be meaningfully presented. At the same time, he would avoid the 'fables' of Christian doctrine, which he had rejected on other grounds. 
Voltaire's philosophy of history, Voegelin said, was no mean achievement. It served as a model for the great speculations of Comte and Marx during the nineteenth century, and for their twentieth-century successors. Whatever one makes of the question of intramundane spirituality, there remains a methodological question common to all historical speculations of the Voltairian type. All stories, whether putatively universal or not, express a unity of meaning. Indeed one may say that the essential or defining element of a story is that it contain and express a unity of meaning. Now, the attempt to create a universal story on the basis of an encyclopedic survey of historical evidence will necessarily be futile unless at the same time one can establish on principle the knowledge that the empirical survey is exhaustive. In other words, no unity of meaning can be established on the basis of a pretended encyclopedic survey unless history is ended and the whole of its course known. This problem was recently rediscovered by Francis Fukuyama. From the perspective of Voltaire's secular and intramundane position, the problem of a unity of meaning presents an insuperable problem because, in principle, only the past can be known. Moreover, the meaning of the past must be conditioned by the present perspective of the author. It is for this reason that the imposing stability of Christian anthropology and Christian theology of history contrasts so strikingly with the instability of intramundane equivalents to sacred history and intramundane anthropologies developed in the aftermath of the so-called Enlightenment. This difficulty has often been analyzed under the topic of historicism. We will, therefore, merely sketch the difficulties.

The dynamic of instability with respect to historicism may be found in Voltaire's evocation of the esprit humain. In light of Bossuet's Christian anthropology, the human spirit, left to its own devices, is apt to err or rebel. In light of Christian theology of history, the intramundane historical consciousness is necessarily predisposed towards novelty and the endless production of expressions of a contemporary sense of epoch. But times change and so do sentiments. This is why Voltaire's evocation of politesse as the goal towards which the labours of history were directed looks so bizarre today, even though a powdered and bewigged French intellectual may provide a more agreeable image of perfected humanity than a Comtean captain of industry, a Marxist proletarian or even a Husserlian functionary of mankind, to say nothing of contemporary vulgarian evocations. In fact, however, the theoretical fallacy lies in the principle of any such evocation and not its contingent content. Moreover, it is not a particularly difficult fallacy to understand, which raises the obvious question: why did Voltaire commit it?

Voegelin provided a brief answer in The New Science of Politics. ${ }^{8}$ By transforming the Christian fulfillment by grace of the Holy Spirit in 
death into the fulfillment of the polite intellectual by grace of the human spirit in life, Voegelin said, Voltaire created an imaginary 'eidos' or essence or meaning to history. But, remarked Voegelin,

Things are not things, nor do they have essences, by arbitrary declaration. The course of history as a whole is no object of experience; history has no eidos, because the course of history extends into the unknown future. The meaning of history, thus, is an illusion; and this illusionary eidos is created by treating a symbol of faith as if it were a proposition concerning an object of immanent experience.

Simply pointing out the fallacious intellectual act does not explain it but, on the contrary, underlines the problem. One cannot assume that Voltaire was too dull to understand the questionable nature of the enterprise, nor that he understood it and went ahead anyway for some dark and malevolent reason. 'Obviously,' Voegelin said, 'such acts cannot be explained simply by stupidity and dishonesty. A drive must rather be assumed in the souls of these men, which blinded them to the fallacy.' One can discover the nature of the 'drive' by considering what was achieved by undertaking the fallacious construction. 'On this point,' he said, 'there is no doubt. They achieve a certainty abut the meaning of history, and about their own place in it, which otherwise they would not have had.' The achievement of certainty, then, eclipses whatever intellectual misgivings one such as Voltaire may have had regarding the incoherence of an argument that appears only to reflective consciousness anyway.

That there is a genuine existential problem involved and not merely an intellectual one is indicated as well by Bossuet's own polemical writings. His Histoire des variations des eglises protestantes $(1688)^{9}$ was a defence of the accumulated wisdom of the Church in the face of protestant individualism. His argument was prudential, not intellectual or rationalist. Christianity, understood as a historical phenomenon and the source of community substance and cohesion in the West, required, he said, the institutional authority of the Church to keep it intact. Without such authority the tradition that sustained the sacredness of religious scripture would dissolve. It was, therefore, less the contents of protestant doctrines that troubled Bossuet than the fact that they were the occasion for schism, and schism, he held, would eventually lead to the historicization of Christianity and thereby to its eclipse. Bossuet's fears were amply confirmed by the time of Voltaire. Even so, Voltaire's theoretical objections to Christian theology of history could not be met simply by pointing to the unhappy consequences of disbelief. 
Voegelin provided his own summary reflections on the continuity of this historical process under the title, 'The Dynamics of Secularization.' This is, of course, a vast and complex topic. We can do no more than hint at its complexity at present. To condense greatly, it was Voegelin's view that what we now refer to as the secularization of history, of which Voltaire's polemical 'philosophy of history' was an important symptom, may more accurately be characterized as the dissociation of the constituent elements of medieval Western universalism, namely spirit, reason and imperium. Regarding the last of these, the remark of Frederick the Great quoted earlier, indicated that the imperium had fragmented into particular national realms. The dissolution of the spiritual-temporal unity of Christendom, articulated into Empire and Papacy and justified by the Gelasian doctrine of the two swords, by Augustine's theology of the two cities, and eventually by the words of Christ (Matt. 22: 21), into the organizational opposition of church (or churches) and state (or states) left open not only the question of the spiritual representation of Western humanity but also the question of what would replace the empire as the basis for order among Western political units.

The second factor to dissociate from the medieval configuration was reason. Beginning in the thirteenth and fourteenth centuries, Averrorism and nominalism developed into the autonomous secular reason and natural law of the seventeenth century. The social order that lent support to this intellectual movement consisted in the array of lawyers, scientists and philosophers outside ecclesiastical orders as well as the royal corps of administrators.

The third factor, the disintegration of the medieval spiritual power into one pole of the church-state pair was perhaps the most complex. According to Voegelin's account, the spiritual ascendancy of the Church was only in part a consequence of its spiritual heritage. It was also an effective civilizing organization by virtue of the institutional and administrative competences that it had acquired through compromise with the surrounding classical and then barbarian civilizations. But by the late middle ages, Europe had begun to develop into a new civilizational order and the novel European communities (in the cities, for example) were entirely capable of continuing Western civilization without the economic and political leadership of the Church. For one reason or another, the Church did not liquidate its economic strength nor abandon its political position. Moreover, as guardian of the civilizational heritage of classical antiquity, the Church was bound eventually to conflict with the civilizational achievements of the growing secular European civilization. In order to preserve its own spiritual mission under these new circumstances, the Church would have had to reach a new compromise, similar in principle to that concluded with Roman civilization in antiq- 
uity. Specifically, it would have had to abandon those elements of its ancient tradition that were incompatible with the new civilization. Again, however, the evidence indicates that the Church was unable to adjust. This was evident as well in the aforementioned doctrinal language of Bossuet.

Voegelin distinguished three general phases in the process by which the medieval unity of imperium, reason and spirit dissociated into modern fragments. The first or 'political' phase extended from about 1300 to about 1500 . The refusal of the Church to reduce its economic and political profile led first to fourteenth-century Anglicanism, then to fifteenth-century Gallicanism and finally to the wholesale confiscations during the Reformation of the sixteenth century. The second phase, extending from about 1500 to about 1700 was focussed on the status of reason. The inevitable friction between the new astronomy and physics and the Babylonian cosmology preserved in the Old Testament led to the celebrated conflicts between Bruno and Galileo, and the Inquisition. The third phase extended from around 1700 to the present, and consists in the great spiritual clash between the modern, critical and secular treatment of sacred texts and sacred history, and the ecclesiastical interpretation of the meaning of faith. In terms of the contrast introduced earlier, the spiritual phase of dissociation is exemplified in the conflict between Voltairian philosophy of history and Augustinian theology of history.

The development of political and of intellectual autonomy, Voegelin's first two phases, had a profound and devastating effect on the institutional position of the Church and thereby induced deep structural fractures into the cultural integrity of Western civilization. The expropriation of Church properties and the growth of sovereign political units acknowledging no legal superior did not by itself impair the spiritual mission and purpose of the Church. The problem lay elsewhere. With the transformation of the medieval tension between spiritual and temporal authority into the modern political conflict between church and state came the privatization of spiritual institutions and the monopoly of the public sphere by the new sovereign political units. As early as the first Diet of Speier (1526) it was decreed that, in matters of faith, princes might act in such a manner as they could answer to God and Emperor. By the Peace of Augsburg (1555) the 'monstrously cynical formula "Cujus Regio, Ejus Religio"', as Toynbee put it, enshrined the destruction of any public representation of spiritual authority as a condition for public peace. ${ }^{10}$

The destruction of public authority in spiritual matters did not mean that Western society carried on as before, with the sole difference being that the traditional spiritual exercises were henceforth undertaken be- 
hind closed doors. On the contrary, the destruction of the Church left a spiritual vacuum that was quickly filled by the new sources of spiritual order: the divine right of kings, nationalism, humanitarianism, liberalism, socialism, racism, pacifism, feminism, and so forth. The plethora of spiritual movements with which modern society has come to be afflicted would, indeed, have confirmed Bossuet's worst fears with respect to schism.

Parallel to the political conflict of church and state and the subsequent eclipse of Christian spirituality, and even more ominous consequence followed from the triumph of autonomous reason in the guise of science. ${ }^{11}$ Here dogmatic resistance by the Church and forcible suppression of speculation by the Inquisition led to the dogmatic counter-dogma that science could provide a substitute for the spiritual integration of human life. As in the political sphere, the consequence was simply to introduce new spiritual forces, this time into the structure of personality not society.

The gravest danger, however, has come from the third phase, the open conflict between Christian symbols and the rationalist and historical critique of them as myths and fables. This de-divinization of the world, as Max Weber called it, both destroyed the usefulness of mythical language to convey experiences of world-transcendent realities and obscured the fact that so-called scientific criticisms are often genuinely obscurantist myths presented by means of conceptual rather than sensual language.

Voegelin's judgement regarding the response of the Church to this third threat or wave of modernity was mixed. On the one hand, he said that the defensive refusal by the Church to employ rationalist language to reduce the mystery of the world-transcendent drama of the soul to the psychodynamics of internal and world-immanent experience could only be admired. Less admirable was the Church's refusal to undertake an active response. 'A problem undeniably exists,' wrote Voegelin,

and it cannot be solved, like the problems of the first and second phases, by a belated acceptance of the new situation. It is not for us to offer a solution; but certainly a part of it would have to be a new Christian philosophy of history and of mythical symbols that would make intelligible, firstly: the new dimension of meaning that has accrued to the historical existence of Christianity through the fact that the Church has survived two civilizations; and that would make intelligible, secondly: the myth, as an objective language for the expression of a transcendental irruption, more adequate and exact as an instrument of expression than any rational system of symbols, [and] not to be misunderstood in a literalism that results from opacity nor reduced to an experiential level of 
psychology. Obviously it is a task that would require a new Thomas rather than a neo-Thomist. ${ }^{12}$

In order to deal with this problem, an act of 'ecclesiastical statesmanship' comparable to that achieved by St. Paul or St. Thomas was required.

The problem, very simply, is that modern, Western civilization does not understand itself as a postscript to antiquity. In their famous quarrel, the moderns as well as the ancients made valid and legitimate claims. If under these new civilizational conditions, the Church did not discern the hand of God in the affairs of human beings, then humans were likely search for or perhaps invent new divinities that showed more interest in their affairs. No deus absconditus is ever likely to be an effective reality save but for a tiny minority. In its past, the early Church was able to absorb and penetrate the civilizational culture of antiquity; after an equally difficult struggle, St. Thomas was able to formulate an acceptable account of imperial Christianity. In contrast, Voegelin said, the modern Church has not risen to the occasion but has, on the contrary, abandoned its magisterium and withdrawn to lament the pride of modern human beings who refuse to submit to its authority.

It may, indeed, be lamentable that the authority of the Church has declined or even disintegrated, but it is certain that it cannot be restored through expressions of regret. When St. Paul, for example, declared in his epistle to the Romans that God has revealed himself to the Gentiles through His creation (Rom. 1:19-20), to the Israelites through the Written Law, and to all by the Law of Christ, graven on the hearts of men (Rom. 2:12 ff), he was able meaningfully to integrate the civilizational substance of the pagan, the Jewish and the Christian communities. No such integration has been achieved by his modern Christian successors.

Voegelin was never so immodest as to claim that he was a new Thomas. Yet, his larger project, to re-establish the foundations of political science, would have to make sense of the failure of the Church to respond to the genuine problems brought to light by Voltaire. When the traditional formulations of Christian sacred history omitted large sections of humanity from a putatively universal spiritual drama, something clearly was wrong. At the same time, Bossuet's fears were not simply those of episcopal traditionalism. A new Thomas would, therefore, develop a philosophy of history that was neither as empirically limited as Bossuet's theology of history, nor as spiritually arid as Voltaire's secular philosophy of history. Such an enterprise, Voegelin said, would have three interrelated components. First, it would balance the universal spiritual insights of a Bossuet with Voltaire's concern for an ecumenical survey of evidence. It would, moreover, be concerned for the historical vicissitudes of the Church as an institution that has attempted to shelter the 
spiritual substance of Christianity from the corrosive influence of two civilizational courses. And third, such a philosophy of history would be sensitive to the intelligibility of symbols as vehicles for the transmission of experiences of world-transcendent realities.

This is, clearly, a tall order to fill and cannot be attempted on the present occasion. Let me, instead, suggest some of the problems involved in the last matter Voegelin mentioned. We can approach this topic usefully by considering the matter of doctrine or dogma.

In the quotation taken from the New Science of Politics Voegelin remarked that one of the consequences of a fallacious construction of the meaning of history - or even of the end of history - is that one obtains 'certainty.' One is interested in certainty for a very good reason, namely to overcome uncertainty and the anxieties that accompany it. More specifically,

uncertainty is the very essence of Christianity. The feeling of security in a 'world full of gods' is lost with the gods themselves; when the world is de-divinized, communication with the world-transcendent God is reduced to the tenuous bond of faith, in the sense of Hebrews 11:1, as the substance of things hoped for and the proof of things unseen. Ontologically, the substance of things hoped for is nowhere to be found but in faith itself; and, epistemologically, there is no proof for things unseen but again this very faith. The bond is tenuous, indeed, and it may snap easily. The life of the soul in openness toward God, the waiting, the periods of aridity and dulness, guilt and despondency, contrition, and repentance, forsakenness and hope against hope, the silent stirrings of love and grace, trembling on the verge of a certainty which if gained is loss - the very lightness of this fabric may prove too heavy a burden for men who lust for massively possessive experience. $^{13}$

Not all who know of the tenuousness of faith reject it in favour of certainty. There exists as well a kind of middle ground, which for present purposes we may identify with doctrine.

In the present example, the Biblical language of the Epistle to the Hebrews is intended to convey an experiential truth. The problem, however, is that it does not refer to existent phenomena but to a consciousness of participation in a nonphenomenal and nonexistent reality. 'As a consequence,' Voegelin observed, 'when the experience engendering the symbols [in this example, 'faith'] ceases to be a presence located in the man who has it, the reality from which the symbols derive their meaning has disappeared. ${ }^{14}$ The mere efflux of time practically ensures that the 'lightness of the fabric,' that is, the full truth of an experience of reality and its symbolic articulation, is ripped into a piece of information and its subject matter. 
And yet, the truth conveyed ever so lightly by language symbols is the source of order in human society. To the anxieties of the experience itself therefore is added the anxiety that the source of order or meaning will be lost. As a consequence now, the pressure is great to restate the exegetic account discursively for the purpose of communication. It may be translated, for instance, into simple propositions, rendering what the translator considers its essential meaning, for use on the secondary level of instruction and initiation. If submitted to such proceedings, for quite respectable purposes, the truth of the account will assume the form of doctrine or dogma, of a truth at second remove, as for instance the propositions 'Man is immortal' or 'The soul is immortal.' Moreover, dogmatic propositions of this kind are liable to condition corresponding types of experience, such as fideistic acceptance or even more deficient modes of understanding ... Even the transformation into doctrine, however, is not the last loss that truth can suffer. When doctrinal truth becomes socially dominant, even the knowledge of the processes by which doctrine derives from the original account, and the original account from the engendering experience, may get lost. The symbols may altogether cease to be translucent for reality. They will, then, be misunderstood as propositions referring to things in the manner of propositions concerning objects of sense perception; and since the case does not fit the model, they will provoke the reaction of skepticism on the gamut from a Pyrrhonian suspense of judgment, to vulgarian agnosticism, and further on to the smart idiot questions of 'How do you know?' and 'How can you prove it?' that every college teacher knows from his classroom. We have reached T.S. Eliot's Waste Land with its broken images:

What are the roots that clutch, what branches grow

Out of this stony rubbish? Son of man,

You cannot say, or guess, for you know only

A heap of broken images, where the sun beats,

And the dead tree gives no shelter, the cricket no relief,

And the dry stone no sound of water. ${ }^{15}$

The sequence of original account, dogmatic exposition, and skeptical argument against the dogma can occur with respect to any experience of nonphenomenal reality, and not just Christianity.

To give but one brief example: in classical antiquity, the culture of the myth (evoked so well a couple of generations ago by Jane Harrison and undergoing a significant revival today) was followed by the noetic experience of philosophy and its literary exegesis in the work of Plato and Aristotle. The exegesis, in turn, was followed by the dogmatic philosophy of the schools and school dogmata were soon enough thrown into doubt by scepticism. It is into this kind of sequence that Voegelin understood 
Voltaire's argument with Bossuet. Let us, then, leave these late formulations of the problem and return to Voegelin's text.

'Voltaire,' said Voegelin, 'was not a systematic thinker.' He did not attack Christian symbols or Christian anthropology on the basis of his own explicit and systematic concepts and arguments. Such an approach

is unnecessary for Voltaire because he is sufficiently equipped with convictions. Heinaugurates the type of man who is at the height of an age that conceives of itself as being at the height of human civilization ... He has developed his intellectual and moral faculties to the point where they can become the standard for others: if Voltaire does not understand Leibniz, the philosopher obviously has written something that he did not understand himself. From the apex of his reason and humanity he can see the evil in the world that is caused by obscurantism and malice; with the fire of tolerance he will attack superstition and persecution, frequently with great courage and at a personal risk. The full consciousness of his superiority does not impair, however, his humility: faced with the mysteries of religion he will frankly admit that he does not understand them and that, therefore, they have to be eliminated from the public scene. The light of reason should fall into every corner of the human mind, and if it falls on a substance that is solid enough not to be dissolved by its rays, the obstacle should be destroyed because it is a scandal to enlightened man. ${ }^{16}$

As for such venerable terms as reason or enlightenment, one finds not a tightly argued position comparable, for example, to that of Kant, but a complex of information and sentiments culled from a wide range of sources. One of the most important in this regard was Newton. His Elements of Newton's Philosophy (1738) establishes fairly clearly the understanding of reason presupposed in his attack on Christianity.

Let us contrast Voltaire's positions regarding the relationship between the soul and God and the account of the spiritual process given by Thomas Aquinas in the Summa contra Gentiles. ${ }^{17}$ According to Thomas, the Christian symbols of the soul and of God and the relations between the two are not dogmatic propositions regarding the relationship between entities or phenomena. Despite the form of presentation, Thomas was not providing his readers with a series of propositions that might be accepted or rejected on the basis of intellectual inspection. Rather he expressed a real movement in the soul of the believer responding to divine grace. In the soul's response, faith is 'formed' by the experience of charity as a response to divine love or grace and is drawn toward God; moreover the soul is conscious of the process as an experience of reality for which the literary text of Thomas is the trace. The concrete experience of this process in the soul of Thomas gave meaning to the theological and anthropological terminology. That is, the actual spiritual process not 
the language of its expression, was the active center of intellectual focus. When that focus is shifted from the substantive experiences of human existence to phenomenal knowledge of the external world, the essential point of the meditative exegesis, namely the expression or articulation of Christian spiritual reality, is lost. Under such circumstances, either the exegetical symbols will be abandoned because they have become irrelevant or, if sentiments in support of tradition remain strong, they will be simplified into psychological dispositions or justified on the basis of social utility. In any event, the experiential meaning evaporates. As Voegelin said, 'That last position, the combination of opaqueness of the symbols with traditional reverence for them, is the position of Newton and Voltaire. ${ }^{18}$

Voltaire nowhere discussed the spiritual processes of the soul. The following is the opening paragraph of his Elements of Newton's Philosophy: 'Newton was deeply persuaded of the existence of God, and he meant by this word not only an infinite, all-powerful, eternal and creative Being, but a master who established a relation between himself and his creatures: for, without this relation, knowledge of a God is but a sterile idea that would seem to invite crime, by the hope of impunity, every thinker having been born perverse. ${ }^{19}$ Newton happened to believe in God. This biographical accident was Voltaire's starting point. There followed a conceptual specification of the meaning of the word God and finally the reasoning that is meant to account for Newton's having been persuaded to believe. The focus is not on spiritual reality experienced but on externally described psychological facts. The spirituality expressed by Voltaire's account reminds one of the cri de coeur by Glaucon Adeimantus in book 2 of the Republic, with the difference, of course, that Plato's dramatic characters sought deliverance. The consciousness typified by Voltaire is so far from being aware of a need for deliverance from the climate of opinion that characterized his age that, as Voegelin remarked, he could conceive of himself as the standard by which all others might be judged. Moreover, he was untroubled by his own perverseness because he considered it an occupational characteristic of 'all thinkers.'

It is possible to cut through the spiritual fogginess of Voltaire's account with the observation that the perversity of the thinker exists only insofar as his existence is no longer ordered by the response of faith (formed by love) to divine grace. Because of this perversity, society was required to intervene to establish order; it did so by providing a content to the otherwise empty 'idea' of God. The content was revenge and punishment for criminality, a somewhat more primitive conception of divine spirituality than is found in Thomas's exegesis of grace. According to Voltaire, belief in divine punishment deters crime; therefore, it is useful to believe in God. It is, perhaps, enough to observe that a Thrasy- 
machus or a Callicles would not be persuaded as easily as Voltaire said Newton had been. On the basis of Voltaire's doctrinal approach to these questions, a person of Calliclean spiritedness would be more likely to take his chances later in order to enjoy a life of pleasurable perverseness now.

It is significant that Voltaire typically would avoid the genuine existential issue in order to present his convictions. Having, therefore, declared in favor of God, Voltaire adduced other evidence to prove the soundness of his decision. Gravity and planetary movements indicated that the hypothesis of a divine artificer was highly probable. The spiritual superficiality of the remark was evident from Newton's reservations on whether God followed the inverse-square rule when assigning the planets their positions. ${ }^{20}$ The spiritual implications were fully exposed when Laplace explained to Napoleon that he had no need of such a hypothesis. In other words, the apparent reasonableness of Voltaire's assertion, that a divine artificer was required to construct the mechanical phenomenon so beautifully described by Newtonian mechanics, required for its plausibility a thoroughly unreasonable commitment to what Whitehead called the fallacy of misplaced concreteness, or, in Christian terms, the 'credo ut intelligam, which presupposes the substance of faith, is reversed into an intelligo ut credam. ${ }^{21}$

Voegelin's point, very simply, is that the experience of a spiritually integrated personality has escaped Voltaire and has been replaced with an intraworldly or world-immanent faith in a society given coherence by means of compassion and humanity. Voltarean humanity according to Voegelin,

is a general disposition in man arising out of his biological structure. Negatively, the reasonable attitude is characterized by the absence of immediate spiritual experiences. As a consequence of this deficiency, the symbolic expressions of spiritual experiences become opaque and are misunderstood as depending for their validity on their resistance to rational critique. The monopoly of legitimate orientation in the world is arrogated, on principle, to the methods of natural science. The remnants of Christian orientation towards the transcendent have to be justified, like the existence of God, in terms of a hypothesis based on the order of nature as revealed in physics, or like the belief in supernatural punishment, on its pragmatic usefulness. The spiritual orientation and integration of personality is ignored as a problem, the principles of ethics are severed from their spiritual roots, and the rules of conduct are determined by the standard of social utility. ${ }^{22}$

Voltaire did not, however, understand that his own criticisms of Christian dogma were themselves driven by a new intraworldly religiousness. 
Just as in his criticism of Bossuet, the motive force that transformed l'esprit humain from darkness and barbarism into polite enlightenment remained obscure, so too with personal ethics: Voltaire did not present himself as revolutionary spiritual founder. Indeed, Voegelin observed, if one subtracts Voltaire's vitality, literary skill and intellectual wittiness we are left, on the negative side, with 'the Homard of Flaubert's Madame Bovary or the exasperating Bouvard and Pecuchet who have to try their hands at everything.' Likewise, on the positive side, he is surely a fine poet, historian, essayist and, indeed, 'one of the greatest men of letters, but the range and quality of the performance can never quite anesthetize the awareness of the ultimate defect of substance. ${ }^{, 23}$

Such limitations do not render Voltaire superficial. He has rightly been praised for his courage and commonsense, for his tolerance and hatred of bigotry and oppression. His great strength, therefore, lies 'in this twilight zone of procedural virtues,' not spiritual substance. Moreover, they are tied to the particularities of his own situation as one who

has lost the old faith sufficiently to see its shortcomings as an outsider and to attack them without compunction, and who has not enough substance of the new faith to create its law as the master but enough to fight with skill and courage for its establishment. This intermediate position is the soil for the style of critique and attack, of proselytizing and defense, sarcasm and satire, which Voltaire has developed to perfection. It is a realm not of the spirit, but between the spirits, where man can live for a moment in the illusion that he can, by discarding the old spirit, free himself of the evil which inevitably arises from the life of the spirit in the world, and that the new one will create a world without evil. The protest against the world and the cry for the light are futile if we expect to find the light in the world, but even this futility and illusion are still ennobled by the contemptus mundi, by a glimpse of the light and a sincere desire for deliverance from the evil. The child-of-the-world's dream of a terrestrial paradise of compassion and humanity is only a shadow of the heavenly city, but still it is a shadow cast by the eternal light. ${ }^{24}$

Voltaire's dream of a paradise of compassion was possible only because he experienced in his own person the qualities he extolled. Whatever the defects of his anthropology considered as a piece of systematic speculation, its significance lay elsewhere, namely in the historical fact that men such as Voltaire could turn against the Church on the basis of compassion for the suffering creature. One may link his criticism of Bossuet's theology of history to his more spectacular, vulgar and spiritually insensitive criticisms of Christianity with the observation that in both realms of discourse he was insisting that human being in history and society be 
recognized as part of divine creation and to be acknowledged with compassion.

It may be considered unfortunate that the institutions of the spirit had sunk so low at the time that a Voltaire had to devote himself to the task and to act with authority as the defender of man in historical society, but one cannot deny that he acted with grandeur the role of a defensor humanitatis against the professionals of the faith. ${ }^{25}$

On the basis of the foregoing remarks, one may venture the following conclusion: Voegelin's understanding of Voltaire's achievement as a philosopher of history in the non-polemical (or non-Voltairean) sense balanced an awareness the virtue of his acknowledgement of the range of evidence with an awareness of Voltaire's shortcomings as a thinker.

\section{BARRY COOPER}

University of Calgary

\section{Notes}

1 (Durham: Duke University Press, 1975) 3-34.

2 Voegelin, Order and History, vol. I, Israel and Revelation (1956); vol. II, The World of the Polis (1957); vol. III, Plato and Aristotle (1957); vol. IV, The Ecumenic Age (1974). All were published by Louisiana State University Press, Baton Rouge, LA. Anamnesis: Zur Theorie der Gesichichte und Politik (Munich: Piper, 1966).

3 Frederick to Voltaire, 26 October 1740, in Les Oeuvres complètes de Voltaire, vol. 91 (Geneva, Institut et Musée Voltaire, 1970), 342.

4 See Karl Löwith Meaning in History (Chicago: U of Chicago P, 1949) ch. 5.

5 Voltaire, Oeuvres complètes de Voltaire, vol. 7, (Paris: Furne, 1846) 684 (Dictionnaire philosophique, article, 'Histoire,' section 2).

6 Voltaire, Remarques, Oeuvres, vol. 21, 264.

7 Voltaire, Remarques, III, pp. $266 \mathrm{ff}$.

8 Chicago: University of Chicago Press, 1952. Quotations are taken from 120-22.

9 Oeuvres complètes, vol. IV (London: Guérin, 1862) 410ff.

10 Toynbee, A Study of History (Oxford: OUP, 1939) IV, 221.

11 See Voegelin, 'The Origins of Scientism,' Social Research, 15 (1948), 462-94.

12 Voegelin, From Enlightenment to Revolution 22.

13 Voegelin, The New Science of Politics 122. 
14 Voegelin, The Collected Works of Eric Voegelin, vol. XII, Published Essays, 1966-1985, ed. E. Sandoz, (Baton Rouge, Louisiana State University Press, 1990) 52.

15 Voegelin, 'Immortality,' 53-4.

16 Voegelin, From Enlightenment to Revolution 23-4.

17 Book 3, Ch. 151-53. The text used was translated by Vernon J. Bourke, (Notre Dame: University of Notre Dame Press, 1975) 233-39.

18 Voegelin, From Enlightenment to Revolution 25.

19 The text used is in the Oeuvres complètes de Voltaire, nouvelle édition, vol. 22 (Paris, Garnier, 1879) 403.

20 Fortunately, Pluto was not discovered until 1930.

21 Voegelin, From Enlightenment to Revolution 26.

22 Voegelin, From Enlightenment to Revolution 29.

23 Voegelin, From Enlightenment to Revolution 32.

24 Voegelin, From Enlightenment to Revolution 32-3.

25 Voegelin, From Enlightenment to Revolution 34. 